\title{
Komunikasi Keluarga dalam Membentuk Karakter Anak
}

\author{
Jefrey Oxianus Sabarua1, Imelia Mornene ${ }^{2}$
}

${ }^{13}$ Prodi Pendidikan Guru Sekolah Dasar, Universitas Halmahera, Indonesia

\section{A R T I C L E I N F O \\ Article history: \\ Received 18 Desember 2019 \\ Received in revised form 30 Desember 2019 \\ Accepted 15 Januari 2020 \\ Available online 20 \\ Februari 2020 \\ Kata Kunci: \\ Cara komunikasi keluarga \\ karakter siswa}

Keywords:

How to Family

Communication, Student

Character

\begin{abstract}
A B S T R A K
Keluarga merupakan tempat utama pembentukan karakter anak. Komunikasi orang tua berkedudukan sebagai pengarah dan pembentuk pola dan perilaku anak, karena pada usianya komunikasi yang dilakukan antara orang tua dengan anak akan menjadi contoh bagi dirinya yang kelak secara otomatis membentuk karakter anak tersebut. Oleh karena itu penulis melakukan penelitian dengan judul; Cara komunikasi keluarga dalam membentuk karakter anak pada siswa kelas IV SD Inpres 3 Wosia kecamatan Tobelo Tengah. Metode yang digunakan dalam penelitian ini adalah metode kualitatif deskriptif, dan prosedur pengumpulan data yang digunakan adalah observasi, wawancara dan dokumentasi. Hasil penelitian menemukan bahwa pola komunikasi yang digunakan oleh orang tua sama dengan pola komunikasi yang digunakan oleh anak pada saat ia berkomunikasi di lingkungan sekolah. Hal tersebut sejalan dengan pernyataan wali kelas tentang pola komunikasi siswa di lingkungan sekolah.
\end{abstract}

\section{A B S T R A C T}

Family is the main place for the character formation of a child. Communication of parents is located as a director and pattern maker and personal child, because at the age of communication between parents and children will be an example for him who will automatically form the character of the child. Therefore the author conducted a study entitled: The Way of Family Communication in Forming the Character of Children in Class IV Students of SD Inpres 3 Wosia, District of Central Tobelo. This research method is descriptive qualitative method, and the procedure for collecting data is observation, interviews and documentation. The results of the study are seen in the results of interviews of parents who use communication patterns in families, and students who use communication patterns just like their parents when communicating in the school environment and homerooms who provide statements about students' communication patterns in the school environment

Copyright (C) Universitas Pendidikan Ganesha. All rights reserved.

\section{Pendahuluan}

Hidup bermasyarakat merupakan ciri manusia sebagai makhluk sosial, oleh karena itu manusia tidak dapat hidup sendiri dan masih memerlukan bantuan orang lain. Kebutuhan memerlukan bantuan orang lain inilah yang menimbulkan interaksi antar sesama manusia (Mubarok \& Adnjani, 2014: 07). Interaksi dapat berlangsung dengan teratur dan dinamis apabila terjadi proses memberi dan menerima secara positif sehingga saling menguntungkan. Dari proses interaksi sesama manusia menimbulkan hasrat berkomunikasi (Kurniawati, 2014: 79).

Secara etimologis istilah komunikasi berasal dari bahasa latin yaitu communication yang akar katanya adalah communis yang artinya" sama"dalam arti "sama makna" yaitu sama makna mengenai suatu hal. Jadi komunikasi berlangsung bila antara orang-orang yang terlibat terdapat kesamaan makna mengenai suatu hal yang dikomunikasikan, sehingga hubungan mereka bersifat komunikatif (Effendy, 2000: 3). Secara terminologis, komunikasi berarti proses penyampaian suatu oleh seseorang kepada orang lain. Dari pengertian ini jelas bahwa komunikasi melibatkan sejumlah orang, yang menyatakan sesuatu kepada orang lain. Komunikasi diartikan sebagai proses penyampaian suatu pernyataan (informasi), atau

\footnotetext{
1 Corresponding author.
}

E-mail addresses: sabarua.jr@gmail.com¹(Jefrey); Imelia98moronene@gmail.com²(Imelia) 
penyampaian gagasan tetapi sudah melibatkan pengirim dan penerima pesan secara aktif-kreatif dalam penciptaan arti dari pesan yang disampaikan (Irawan Prasetya, Suciati, Wardani, 2000 : 70). Dalam pengertian prakmatis, komunikasi mengandung tujuan tertentu; ada yang dilakukan secara lisan, tatap muka atau via media massa maupun media nonmassa. Jika ditinjau dari segi penyampaian pesan, komunikasi pragmatis bersifat informative dan persuasive.Komunikasi persuasive lebih sulit dari komunikasi informative karena dengan pengandalan komunikasi pengandalan persuasive tidak mudah mengubah sikap, pendapat perilaku orang lain dalam berbagai kesempatan dan tempat tertentu misalnya dalam keluarga, di sekolah atau di masyarakat (Effendy, 2000: 5).

Dedy Mulyana (2005:8) berpendapat bahwa komunikasi berfungsi untuk : (1) Menginformasikan/ to inform, (2) Mendidik/ to educate, (3) Menghibur/ to entertain, dan (4) Mempengaruhi/ to influence. Pola komunikasi biasa disebut dengan model yaitu sistem yang terdiri atas berbagai komponen yang berhubungan satu sama lain untuk mencapai tujuan pendidikan.

Suranto (2010: 195) menyatakan bahwa komunikasi merupakan suatu proses interaksi, karena komunikasi adalah kegiatan dinamis yang berlangsung secara berkesinambungan. Komunikasi juga menunjukkan suasana aktif, diawali dari seorang komunikator menciptakan dan menyampaikan pesan, menerima umpan balik dari komunikan, dan begitu seterusnya pada hakikatnya menggambarkan suatu proses yang senantiasa berkesinambungan. Komunikasi yang efektif ditandai dengan adanya pengertian, dapat menimbulkan kesenangan, mempengaruhi sikap, meningkatkan hubungan sosial yang baik, dan pada akhirnya menimbulkan suatu tindakan. Adapun satu hal yang sangat dibutuhkan oleh seorang anak yaitu jalinan komunikasi yang baik dan berkualitas. Melalui keluarga, anak dibimbing untuk mengembangkankemampuan dan kreativitasnya serta menyimak nilai-nilai soial yang berlaku. (Sari, dkk (2010:36).

Keluarga merupakan kelompok sosial pertama dalam kehidupan manusia pada saat ia belajar dan menyatakan diri sebagai manusia sosial, dalam interaksi dalam kelompoknya. Dalam keluarga yang sesungguhnya komunikasi merupakan sesuatu yang harus dibina sehingga anggota keluarga merasakan ikatan yang dalam, serta saling membutuhkan (Kurniadi, 2010: 271). Secara sadar maupun tidak, dalam sebuah keluarga selalu terjadi proses pembentukan karakter yang kelak menjadi bekal kehidupan bagi anak dalam proses bersosial (Handayani, 2016: 63). Dengan kata lain Komunikasi merupakan salah satu cara yang paling tepat dalam membentuk karakter anak dalam keluarga.

Menurut Aziz Safrudin (2015:235), komunikasi keluarga adalah suatu pengorganisasian yang menggunakan kata-kata, sikap tubuh, intonasi suara, tindakan untuk menciptakan harapan image, ungkapan perasaan serta saling membagi pengertian. Dilihat dari pengertian di atas bahwa kata-kata, sikap tubuh, intonasi suara, dan tindakan, mengandung maksud mengajarkan, mempengaruhi dan memberikan pengertian. Sedangkan tujuan pokok dari komunikasi ini adalah memprakarsai dan memelihara interaksi antara satu anggota dengan anggota lainnya sehingga tercipta komunikasi yang efektif.

Pada hakikatnya komunikasi dalam sebuah keluarga khususnya antara orang tua dengan anak memiliki kontribusi yang luar biasa bagi keduanya, karena dengan adanya komunikasi yang efektif dan efisien yang dilaksanakan secara terus menerus dapat menciptakan keakraban, keterbukaan, perhatian yang lebih antara keduanya serta orang tua pun lebih dapat mengetahui perkembangan pada anak baik fisik maupun psikisnya.

Thomas Lickona (2013: 81) mengemukakan bahwa karakter adalah suatu watak terdalam untuk merespon situasi yang menurut moral baik. Karakter adalah watak, tabiat, akhlak, atau kepribadian seseorang yang terbentuk dari hasil internalisasi berbagai kebajikan yang diyakini dan digunakan sebagai landasan untuk cara pandang, berpikir, bersikap, dan bertindak. Kebajikan terdiri atas sejumlah nilai, moral, dan norma, seperti jujur, berani bertindak, dapat dipercaya, religius, percaya diri, simpati, empati, dan lain lain. Karakter terbentuk karena adanya interaksi seseorang dengan lingkungan sosial dan budaya yang bersangkutan. Dampak jenis interkasi yang dilakukan dalam keluarga dalam kehidupan sehari-hari, meimbulkan adanya perbedaan pembentukan karakter yang berbeda pada setiap anak. Ada anak yang pendiam, percaya diri, senang bekerja sama, empati, jujur bertanggung jawab dan lain-lain. Kemudian ada juga contoh anak yang pemalu, kurang bersosialisasi cenderung kasar, suka melawan orang tua, nakal, mementingkan diri sendiri, tidak jujur dan lain-lain, yang mengarah pada karakter anak ke arah negatif. Hal ini sangat berkaitan dengan cara komunikasi keluarga dalam hal ini orang tua, yang menjadi pembimbing anak tersebut dalam masa pertumbuhan karakternya.

Orang tua yang cenderung mendidik anak tersebut dengan komunikasi yang lembut, mengedepankan kerja sama, terbuka, jujur, serta dengan penuh cinta kasih, pembentukan anak tersebut juga akan seperti itu. Sama halnya dengan orang tua yang selalu menunjukkan sifat atau kebiasaan kasar, kurang peduli, sering mengatakan yang tidak jujur agar apa yang dikehendakinya tercapai, memaksa kehendak sendiri, kemungkinan anak-anaknya akan mengikuti apa yang menjadi sifat dan kebiasaan 
orang tua tersebut (Solihat, 2005: 307-308). Hal tersebut jika ditiru oleh anak - anak, maka akan menyebabkan terbentuknya karakter negatif anak.

Karakter negatif anak terbentuk dari penyimpangan karakter positif sehingga menimbulkan perilaku menyimpang. Imron (2015: 4) menyebutkan bahwa terdapat 18 karakter negatif yang meliputi; tidak agamais, curang, intoleran, indisipliner, malas, tidak kreatif, bergantung, tidak demokratis, masa bodoh, tidak punya rasa kebanggaan berbangsa, tidak cinta tanah air, tidak menghargai prestasi, tidak bersahabat, suka berkonflik/bertengkar, malas membaca, tidak peduli lingkungan, tidak punya kepedulian social, dan tidak bertanggung jawab.

Berdasarkan hasil pengamatan peneliti di SD Inpres 3 Wosia ditemukan beberapa anak-anak yang berkarakter kurang baik. Terlihat karakter negatif mereka ketika berkomunikasi dengan temannya di lingkungan sekolah. Karakter negatif yang terlihat pada siswa yaitu suka berlaku kasar kepada temannya (kata/tindakan), tidak suka menerima saran dari orang lain, tidak peduli dengan temannya yang kesusahan (tidak bawa uang jajan), sering berkata tidak jujur, dan ketika menolong orang lain harus ada imbalan. Salah satu penyebabnya adalah bagaimana cara berkomunikasi orang tua dengan anak. Secara tidak langsung alsalan anak mempunyai karakter yang negative adalah bagaimana cara orang tua berinterkasi dilingkungan keluarga.

Keluarga merupakan lingkungan pendidikan utama anak dalam mengenal segala sesuatu hingga mereka menjadi tahu dan mengerti. Ketika peran dalam kehidupan keluarga lebih khusus orang tua diabaikan maka akan berpengaruh pada karakter anak. Oleh karena itu orang tua bertanggung jawab atas proses pembentukan karakter anak, sehingga diharapkan selalu memberikan arahan, mengawasi dan membimbing perkembangan anak melalui interaksi yang dibangun dalam bentuk komunikasi yang baik antara orang tua dengan anak dalam lingkungan keluarga. Setiap kelauarga mempunyai pola-pola tersendiri dalam berkomunikasi dengan anak.

Pola komunikasi biasa disebut dengan model yaitu sistem yang terdiri atas berbagai komponen yang berhubungan satu sama lain untuk mencapai tujuan pendidikan. Pola komunikasi merupakan suatu sistem penyampaian pesan melalui lambang tertentu, mengandung arti dan pengoperan perangsang untuk mengubah tingkah laku individu lain (Djamarah, $2014: 1$ ). Terdapat tujuh pola komunikasi keluarga menurut para ahli diantaranya; pola komunikasi permisif, pola komunikasi otoriter, pola komunikasi demokratis, pola komunikasi fathernalistik, pola komunikasi manipulasi, pola komunikasi transaksi, dan pola komunikasi pamrih.

Pola komunikasi permissif (cenderung membebaskan) adalah pola komunikasi yang dalam hubungan komunikasi orang tua bersikap tidak peduli dengan apa yang akan terjadi kepad anaknya, orang tua cenderung tidak merespon atau tidak menanggapi, jika anak berbicara atau mengutarakan pendapatnya. Dalam banyak hal juga anak terlalu di beri kebebasan untuk mengambil keputusan.Jadi anak merasa tidak diperdulikan oleh orang tuanya, bahkan ketika anak melakukan suatu kesalahan orang tua tidak menanggapi sehingga anak tidak mengetahui dimana letak kesalahannya atau hal-hal yang semestinya tidak terjadi dapat terulang berkali-kali. Maka anak tersebut akan merasa bahwa masih banyak yang kurang atau anak tersebut masih merasa diri tidak mampu, maka anak pun menjadi kehilangan rasa percaya diri. Bukan hanya itu, anak akan memiliki sifat suka mendominasi, tidak jelas arah hidupnya, prestasinya yang rendah dan terkadang anak tidak menghargai orang lain, selalu mementingkan dirinya dan tidak memiliki rasa empati terhadap orang lain (Yusuf Syamsu, 2001:51).

Pola komunikasi otoriter adalah tipe pola komunikasi yang memaksakan kehendak. Orang tua cenderung sebagai pengendali/pengawas (controller) terhadap pendapat anak, sangat sulit menerima saran dan cenderung memaksakan kehendak dalam perbedaan dan terlalu percaya pada diri sendiri sehingga menutup diri dalam musyawarah. Dalam upaya mempengaruhi anak sering mempergunakan pendekatan (approach) yang mengandung unsur paksaan atau ancaman, kata-kata orang tua adalah hukum atau peraturan yang tidak dapat diubah, memonopoli tindak komunikasi dan seringkali meniadakan umpan balik dari anak. Hubungan antar pribadi orang tua dan anak cenderung renggang dan berpotensi antagonistic (berlawanan) (Djamarah, 2014:60).

Pola komunikasi demokratis adalah tipe pola komunikasi yang terbaik dari semua tipe pola komunikasi yang ada, hal ini disebabkan tipe demokratis ini selalu mendahulukan kepentingan bersama di atas kepentingan individu. Tipe ini adalah tipe pola asuh orang tua yang tidak banyak menggunakan kontrol kepada anak. Beberapa ciri pola komunikasi yang demokratis adalah sebagai berikut: 1) Dalam proses pendidikan terhadap anak selalu bertitik tolak dari pendapat manusia. 2) Orang tua selalu menyeleraskan kepentingan dan tujuan pribadi dengan kepentingan anak. 3) Orang tua senang menerima saran, pendapat dan bahkan kritik dari anak. 4) Mentolerir ketika anak membuat kesalahan dan memberikan pendidikan kepada anak agar jangan membuat kesalahan dengan tidak mengurangi daya kreatifitas, inisiatif dan prakarsa anak. 5) Lebih menitik beratkan kerja sama dalam mencapai tujuan. Dan 6) Orang tua selalu berusaha untuk menjadikan anak lebih sukses darinya. 
Tipe pola komunikasi demokratis mengharapkan anak untuk berbagi tanggung jawab dan mampu mengembangkanpotensi kepemimpinan yang dimilikinya. Memiliki kepedulian terhadap hubungan antar pribadi dalam keluarga. Meskipun tampak kurang terorganisasi dengan baik, namun gaya ini dapat berjalan dalam suasana yang rileks dan memiliki kecenderungan menghasilkan produktifitas dan kreatifitas, karena tipe komunikasi demokratis ini mampu memaksimalkan kemampuan yang dimiliki anak (Djamarah, 2014:61).

Pola komunikasi Fathernalistik (fathernal=kebapakan) adalah pola komunikasi kebapakan, di mana orang tua bertindak sebagai ayah terhadap anak dalam perwujudan mendidik, mengasuh, mengajar, membimbing dan menasihati. Orang tua menggunakan pengaruh sifat kebapakannya untuk menggerakan anak mencapai tujuan yang diinginkan meskipun terkadang pendekatan yang dilakukan bersifat sentimental. Dibalik kebaikannya, kelemahannya adalah tidak memberikan kesempatan kepada anak untuk tumbuh menjadi dewasa dan bertanggung jawab. Itulah sebabnya, tipe pola komunikasi ini diberi ciri-ciri berdasarkan sifat-sifat orang tua sebagai pemimpin. Diantara sifat-sifat umum ini tipe pola komunikasi kebapakan adalah orang tua menganggap anak sebagai manusia yang tidak dewasa, terlalu melindungi anak, tidak memberi kesempatan kepada anak untuk mengambil keputusan dan untuk mengembangkan inisiatif dan kreasi, orang tua sering menganggap dirinya serba tahu (Djamarah, 2014 : 62).

Pola Komunikasi Manipulasi adalah pola komunikasi yang selalu melakukan tipuan, rayuan, memutar balik kenyataan. Agar apa yang dikendaki tercapai, orang tua menipu dan merayu anak agar melalukan yang dikehendakinya. Pola komunikasi orang tua yang bergaya manipulasi biasanya berhasil mencapai tujuan karena anak yang diperlakukan tidak tahu maksud orang tuanya (Djamarah, 2014 : 64).

Pola Komunikasi Transaksi adalah pola komunikasi orang tua tipe ini selalu melakukan perjanjian (transaksi), di mana orang tua dengan anak membuat kesepakatan dari setiap tindakan yang diperbuat. Ada sanksi tertentu yang dikenakan kepada anak jika suatu waktu anak melanggar perjanjian tersebut (Djamarah, $2014: 64$ ).

Pola Komunikasi Pamrih adalah pola komunikasi yang setiap hasil kerja yang dilakukan ada nilai material.Bila orang tua ingin menggerakan anak untuk melakukan sesuatu, maka ada imbalan jasanya dalam bentuk material.Jadi karena ingin mendapatkan imbalan jasa anak terdorong melakukan sesuatu yang diperintah sesuatu (Djamarah, 2014:66).

Tujuan penelitian ini adalah untuk mengetahui efektivitas pola komunikasi keluarga dan dampak pola komunikasi orang tua dalam pembentukan karakter anak pada siswa kelas IV SD Inpres 3 Wosia Kecamatan Tobelo Tengah.

\section{Metode}

Penelitian ini dilakukan untuk mengetahui efektivitas pola komunikasi keluarga dalam pembentukan karakter anak dan dampak dari pola komunikasi orang tua dalam membentuk karakter anak pada siswa kelas IV SD Inpres 3 Wosia Kecamatan Tobelo Tengah. Tipe penelitian ini adalah deskriptif kualitatif dengan pendekatan fenomenologi. Adapun data penelitian adalah data terkait pola komunikasi keluarga dalam pembentukan karakter anak, yang melibatkan 10 orang tua, 10 orang siswa, dan 1 orang guru kelas IV.

Teknik pengumpulan data dalam penelitian ini adalah observasi, dokumentasi, dan wawancara. Data yang diperoleh dalam penelitian ini kemudian dianalisis menggunakan teknik analisis deskriptif kualitatif dengan tiga alur yakni: 1) reduksi data, 2) penyajian data, 3) penarikan kesimpulan. Kemudiandata tersebut diuji keabsahan datanya menggunakan triangulasi teori (Moleong, 2009: 324) dan menggunakan bahan referensi.

Tabel 01. Kisi - kisi wawancara

\begin{tabular}{l|ll|l|l}
\hline No & Teori & Indikator & Bentuk Pertanyaan \\
\hline 1 & $\begin{array}{l}\text { Pola komunikasi } \\
\text { (Djamara h,2014) }\end{array}$ & $\begin{array}{l}\text { Orang tua sulit menerima } \\
\text { saran, cenderung memaksakan } \\
\text { kehendak, dan terlalu percaya } \\
\text { diri }\end{array}$ & $\begin{array}{l}\text { Bagaimana caranya Bapak/Ibu } \\
\text { Menggerakan anak untuk } \\
\text { melakukan sesuatu? }\end{array}$ \\
\hline
\end{tabular}




\begin{tabular}{|c|c|c|c|}
\hline 2 & $\begin{array}{l}\text { Pola komunikasi } \\
\text { fathernalistik } \\
\text { (Djamarah,2014) }\end{array}$ & $\begin{array}{l}\text { Orang tua menganggap anak } \\
\text { sebagai manusia yang } \\
\text { Tidak dewasa, terlalu } \\
\text { melindungi anak, tidak } \\
\text { memberi kesempatan kepada } \\
\text { anak untuk melakukan tugas } \\
\text { dan Tanggungjawabnya } \\
\text { sendiri }\end{array}$ & $\begin{array}{l}\text { Apakah Bapak/Ibu sering } \\
\text { memberikan kesempatan kepada } \\
\text { anak untuk melakukan tugas dan } \\
\text { Tanggung jawabnya sendiri? }\end{array}$ \\
\hline 3 & $\begin{array}{l}\text { Pola kumunikasi manipulasi. } \\
\text { (Djamarah,2014) }\end{array}$ & $\begin{array}{l}\text { Orang tua melakukan tipuan } \\
\text { dan rayuan agar anak } \\
\text { melakukan apa yang } \\
\text { dikehendakinya. }\end{array}$ & $\begin{array}{l}\text { Pernahkah Bapak/Ibu melakukan } \\
\text { rauyan/tipuan untuk mencapai } \\
\text { apa yang diinginkan ketika hal } \\
\text { tersebut dihalangi atau tidak } \\
\text { disetujui oleh anak? }\end{array}$ \\
\hline 4 & $\begin{array}{l}\text { Pola komunikasi permissive } \\
\text { (Yusuf syamsu, 2001) }\end{array}$ & $\begin{array}{l}\text { Orang tua bersikap tidak } \\
\text { peduli cendrung tidak } \\
\text { merespon atau tidak } \\
\text { menanggapi anak berbicara } \\
\text { atau berpendapat. }\end{array}$ & $\begin{array}{l}\text { Bagaimana Bapak/Ibu merespon } \\
\text { atau menganggapi ketika anak } \\
\text { ingin menceritakan sesuatu atau } \\
\text { ingin mengutarakan } \\
\text { pendapatnya? }\end{array}$ \\
\hline 5 & $\begin{array}{l}\text { Pola komunikasi demokrasi } \\
\text { (Djamarah,2014) }\end{array}$ & $\begin{array}{l}\text { Orang tua mendahulukan } \\
\text { kepentingan dan tujuan anak } \\
\text { di atas kepentingan pribadi, } \\
\text { senang menerima saran, } \\
\text { pendapat bahkan kritik dari } \\
\text { anak dan juga senang dalam } \\
\text { bekerja sama ungtuk } \\
\text { mencapai suatu tujuan } \\
\text { keluarga . }\end{array}$ & $\begin{array}{l}\text { Bagamana cara Bapak/Ibu } \\
\text { menyelaraskan kepentingan } \\
\text { pribadi dengan kepentingan anak }\end{array}$ \\
\hline 6 & $\begin{array}{l}\text { Dampak psikomotorik pola } \\
\text { komunikasi otoriter. } \\
\text { (Nurani Soyomukti,2010) }\end{array}$ & $\begin{array}{l}\text { Anak sulit menerima saran, } \\
\text { cendrung memaksa kehendak } \\
\text { dan terlalu percaya diri } \\
\text { sehingga menutup diri dalam } \\
\text { musyawarah }\end{array}$ & $\begin{array}{l}\text { Bagaimana kamu menanggapi } \\
\text { ketika saran/pendapatmu tidak } \\
\text { diterima oleh orang lain? }\end{array}$ \\
\hline 7 & $\begin{array}{l}\text { Dampak efektif pola } \\
\text { komunikasi fathernalistik. } \\
\text { (Nurani Soyomukti,2010) }\end{array}$ & $\begin{array}{l}\text { Anak bersifat tidak dewasa } \\
\text { dan tidak bertanggungjawab }\end{array}$ & $\begin{array}{l}\text { Apakah kamu selalu melakuakan } \\
\text { tugas dan tanggungjawabmu } \\
\text { sendiri tanpa ada bantuan dari } \\
\text { orang lain dengan benar? }\end{array}$ \\
\hline 8 & $\begin{array}{l}\text { Dampak psikomotorif pola } \\
\text { komunikasi manipulasi. } \\
\text { (Nurani Soyomukti,2010) }\end{array}$ & $\begin{array}{l}\text { Anak bersifat tidak jujur agar } \\
\text { keinginannya terwujud }\end{array}$ & $\begin{array}{l}\text { Bagaimana caranya mencapai } \\
\text { keinginnanmu ketika hal tersebut } \\
\text { dihalangi/tidak disetujui oleh } \\
\text { orang lain. }\end{array}$ \\
\hline 9 & $\begin{array}{l}\text { Dampak efektif pola } \\
\text { komunikasi } \\
\text { permissive.(Nurani } \\
\text { Soyomukti,2010) }\end{array}$ & $\begin{array}{l}\text { Ana memiliki sikap tidak } \\
\text { menghargai pendapat orang } \\
\text { lain, selallu mementingkan } \\
\text { diri sendiri, dan tidak } \\
\text { memiliki rasa empati } \\
\text { terhadap orang lain }\end{array}$ & $\begin{array}{l}\text { Bagaimana caranya kamu } \\
\text { menanggapi ketika temanmu } \\
\text { yang ingin menceritakan sesuatu? }\end{array}$ \\
\hline 10 & $\begin{array}{lr}\text { Dampak efektif pola } \\
\text { kumunikasi } & \text { demokrasi. } \\
\text { (Nurani Soyomukti,2010) }\end{array}$ & $\begin{array}{l}\text { Anak memiliki sikap yang } \\
\text { selalu mendahulukan } \\
\text { kepentingan bersama di atas } \\
\text { kepentingan pribadi, senang } \\
\text { menerima saran, pendapat, } \\
\text { bahkan kritik dari orang lain } \\
\text { dan juga senang dalam } \\
\text { bekerja sama untuk } \\
\text { mencapai sesuatu. }\end{array}$ & $\begin{array}{l}\text { Bagamana caranya kamu } \\
\text { menyelaraskan kepentingan } \\
\text { pribadi dengan kepentingan } \\
\text { orang banyak? }\end{array}$ \\
\hline
\end{tabular}




\section{Hasil dan Pembahasan}

Berdasarkan hasil wawancara, ditemukan dua dari sepuluh responden orang tua tidak menggunakan paksaan ketika hendak mengarahkan anak melakukan sesuatu juga memiliki anak yang tidak memaksakan kehendaknya ketika berbicara dengan temannya di lingkungan sekolah. Hal ini selaras dengan penjelasan dari wali kelas mereka bahwa benar mereka siswa yang tidak selalu memaksakan kehendak jika pendapat mereka itu salah.

Pada pernyataan pertama oleh dua orang tua terlihat tidak menggunakan pola komunikasi otoriter karena memberikan kebebasan kepada anaknya untuk melakukan sesuatu hal. Hal ini sejalan dengan Djamarah, (20014:75) yang menyatakan bahwa pola komunikasi otoriter merupakan pola komunikasi orang tua di mana mereka sulit untuk menerima saran, cenderung memaksakan kehendak, dan terlalu percaya diri. Disamping itu pula, Yusuf (2001: 51) menyatakan bahwa Pola komunikasi otoriter ditandai dengan orang tua yang melarang anaknya dengan mengorbankan otonomi anak. Sama halnya dengan

Karena orang tua tersebut tidak mengunakan pola komunikasi otoriter maka dampak pada karakter anak mereka juga adalah pola komunikasi yang tidak otoriter ketika berbicara dengan orang lain di lingkungan sekolah. Untuk pernyataan kedua, tujuhdarisepuluh responden orang tua selalu memberikan kesempatan kepada anak untuk mengerjakan tugasnya sendiri. Pernyataan siswa bahwa tujuhdarisepuluhdari mereka yang orang tuanya selalu memberikan kesempatankepada mereka untuk mengerjakan tugas dan tanggungjawabnya di rumah juga bertanggung jawab ketika berada dilingkungan sekolah.

Pernyataan inipun di dukung oleh penjelasan wali kelas bahwa benar siswa tersebut rajin mengerjakan tugasnya di sekolah. Dari hasil penelitian tersebut orang tua tidak menggunakan pola komunikasi fathernalistik. Pola komunikasi fathernalistik adalah pola komunikasi orang tua yang menganggap anak sebagai manusia yang tidak dewasa, terlalu melindungi anak, dan tidak memberikan kesempatan kepada anak untuk melakukan tugas dan tanggung jawabnya sendiri (Djamarah, 2014) .

Dampak dari orang tua yang tidak menggunakan polakomunikasi tersebut memiliki anak yang bertanggung jawab dan itu terlihat ketika mereka berada di lingkungan sekolah. Pernyataan ketiga dengan responden orang tua bahwa empat dari sepuluh responden orang tua tidak pernah melakukan tipuan/rayuan untuk mencapai apa yang diinginkan ketika anak menghalangi atau tidak menyetujui apa yang akan mereka lakukan. Pola komunikasi yang tidak digunakan oleh orang tua tersebut adalah pola komunikasi manipulasi. Pola komunikasi manipulasi merupakan pola komunikasi orang tua pada saat mereka melakukan tipuan dan rayuan agar anak melakukan apa yang dikehendakinya (Djamarah, 2014). Karena orang tua memberikan pola yang baik dalam berkomunikasi maka anak juga akan melakukan seperti yang dilakukan oleh orang tuanya di rumah.

Hasil wawancara dengan responden siswa terdapat juga empat dari sepuluh siswa memiliki kejujuran ketika berada di sekolah yang orang tuanya tidak pernah melakukan tipuan/rayuan ketika berkomunikasi dengan anak dalam lingkungan keluarga. Pernyataan ini selaras dengan penjelasan dari guru bahwamereka anak yang jujur ketika berada dalam lingkungan sekolah. Hasil wawancara dari sepuluh siswa memiliki sikap yang selalu mendengar ketika ada teman yang ingin menceritakan sesuatu. Hal tersebut dijelaskan juga oleh wali kelas bahwa memang mereka itu akan dengar ketika temannya inginmenceritakan sesuatu, tetapi jika itu bertolak belakang dengan pendapat mereka maka tidak semuanya dari mereka akan menerima.

Pernyataan kelima, sembilan dari sepuluh responden orang tua selalu mendahulukan kepentingan anak dibandingkan kepentingan pribadinya, mereka akan mengerjakan apa yang menjadi kebutuhan anaknya terlebih dahulu. Pola komunikasi yang digunakan orang tua adalah pola komunikasi demokrasi. Pola komunikasi demokrasi adalah pola komunikasi orang tua yang mendahulukan kepentingan dan tujuan anak di atas kepentingan pribadi, senang menerima saran/ pendapat bahkan kritik dan juga senang dalam bekerja sama untuk mencapai suatu tujuan (Djamarah, 2014).

Dari hasil penelitian yang dilakukan dengan responden orang tua dari siswa SD Inpres 3 Wosia bahwa setiap pola komunikasi yang digunakan oleh orang tua untuk berkomunikasi dengan anaknya dalam lingkungan keluarga membawa dampak pada pembentukan karakter dari anak tersebut. Sebab anak akan meniru apa yang selalu mereka lihat dan dengar setiap hari lebih khusus dalam lingkungan keluarga.

Keluarga merupakan kelompok sosial pertama dalam kehidupan manusia pada saat ia belajar dan menyatakan diri sebagai manusia sosial, untuk interaksi dalam kelompoknya. (Kurniadi, 2010: 271). Dalam keluarga yang sesungguhnya komunikasi merupakan sesuatu yang harus dibina sehingga anggota keluarga merasakan ikatan yang dalam serta saling membutuhkan. 
Pola komunikasi biasa disebut dengan model yaitu sistem yang terdiri atas berbagai komponen yang berhubungan satu sama lain untuk mencapai tujuan pendidikan. Pola komunikasi merupakan suatu sistem penyampaian pesan melalui lambang tertentu, mengandung arti dan pengoperan perangsang untuk mengubah tingkah laku individu lain (Djamarah, $2014: 1$ )

Menurut Aziz Safrudin (2015:235), komunikasi keluarga adalah suatu pengorganisasian yang menggunakan kata-kata, sikap tubuh, intonasi suara, tindakan untuk menciptakan harapan image, ungkapan perasaan serta saling membagi pengertian.

Dilihat dari pengertian di atas bahwa kata-kata, sikap tubuh, intonasi suara, dan tindakan, mengandung maksud mengajarkan,mempengaruhidan memberikan pengertian. Sedangkan tujuan pokok dari komunikasi ini adalah adalah memprakarsai dan memelihara interaksi antara satu anggota dengan anggota lainnya sehingga tercipta komunikasi yang efektif.

\section{Simpulan dan Saran}

Berdasarkan hasil penelitian, pembahasan dan analisis yang di lakukan oleh peneliti, maka pen eliti dapat menyimpulkan bahwa: 1) Cara komunikasi orang tua terhadap anak menggunakan pola komunikasi yang positif dengan menghindari pola komunikasi yang berdampak negatif. Hal ini terbukti dengan hasil wawancara dengan orang tua dua dari sepuluh orang tua tidak menggunakan pola otoriterdalam mengarahkan anak melakukan sesuatu, tujuh dari sepuluh orang tua tidak menggunakan pola fathernalistikkarena memberikan kesempatan kepada anak untuk melakukan tugas dan tanggung jawabnya, empat dari sepuluh orang tua tidak menggunakan pola manipulasi yakni melakukan tipuan agar anak melakukan keinginan orang tua dan sepuluh orang tua tidak menggunakan pola komunikasi permissif yakni pola komunikasi orang tua yang bersikap tidak peduli ketika anak berbicara. Kemudian sembilan dari sepuluh orang tua menggunakan pola komunikasi demokratis yaitu menyelaraskan bahkan lebih mendahulukan kepentingan anak dibandingkan kepentingan pribadinya. Cara komunikasi orang tua membawa dampak bagi anak. Hal ini dibuktikan dengan hasil wawancara siswa dan guru wali kelas IV SD Inpres 3 Wosia, bahwa siswa yang orang tuanya telah disebutkan pada poin 1 memiliki cara komunikasi yang sama seperti yang dilakukan oleh orang tuanya.

Berdasarkan kesimpulan maka peneliti dapat mengemukakan beberapa saran terkait hasil penelitian kepada; 1) Keluarga merupakan kelompok terkecil dalam masyarakat dan pendidikan utama bagi seorang anak. Dalam keluarga yang sesungguhnya komunikasi merupakan sesuatu yang harus dibina sehingga anggota keluarga merasakan ikatan yang dalam serta saling membutuhkan. Pola komunikasi sesungguhnya harus diperhatikan oleh setiap keluarga lebih khusus orang tua ketika berkomunikasi dengan anak, karena hal tersebut akan berdampak pada karakter anak sebab anak sifatnya itu meniru setiap hal yang selalu ia lihat dan dengar. Orang tua harus memprakarsai dan memelihara interaksi antara satu anggota dengan anggota lainnya sehingga tercipta komunikasi yang efektif. 2) Sekolah merupakan lembaga pendidikan kedua dari seorang anak untuk mengenal bahkan mengetahui segala sesuatu. Guru berperan penting dalam mengajar, mendidik dan mendewasakan anak di sekolah. Oleh karena itu guru perlu memperhatikan setiap siswa yang menggunakan pola komunikasi yang kurang baik dan dapat memberikan bimbingan khusus bagi siswa-siswa tersebut. 3) Masyarakat adalah lingkungan ketika dari anak untuk belajar akan segala sesuatu. Oleh sebab itu masyarakat diharapkan dapat mendukung perkembangan anak baik itu dalam aspek kognitif, afektif maupun psikomotorik.

\section{Daftar Rujukan}

Abdul Majid dan Dian Andayani. 2011. Pendidikan Karakter Perspektif Islam. Bandung: Remaja Rosda

Karya Aziz, Safrudin. 2015. Pendidikan Keluarga Konsep dan Strategi. Yogyakarta: Gava Media.

Abdullah Munir. 2010. Pendidikan Karakter; Membangun Karakter Anak Sejak Dari Rumah. Yogyakarta: Pustaka Insan Madani.

Djamarah, Sayful Bachri. 2014. Pola Komunikasi Orang Tua dan Anak dalam Keluarga. Jakarta: Rineka Cipta.

Effendy Onong Uchjana. 2000. Dinamika komunikasi. Bandung. Remaja Rosdakarya.

Fajarwati, Mila. 2011. Penelitian Pola Komunikasi Orang Tua dengan Anak Remaja dalam Berinternet Sehat di Surabaya, Yayasan Kesejahteraan Pendidikan dan Perumahan Universitas Pembangunan Nasional Veteran, Jawa Timur (pdf). http://eprints.upnjatim.ac.id/1793/ (diakses tanggal 10 Januari 2020) 
Haedar Nashir. 2013. Pendidikan Karakter Berbasis Agama dan Budaya. Yogyakarta : Multi Presindo.

Handayani M. 2016. Peran Komunikasi antar Pribadi dalam Keluarga untuk Menumbuhkan Karakter Anak Usia Dini. Jurnal Ilmiah Visi PPTK PAUDINI. Vol. 11. No. 01. Hal 57 - 64.

Irawan Prasetya, Suciati, Wardani. 2000.Teori Belajar Motivasi dan Keterampilan mengajar.Pusat antar Universitas untuk Peningkatan dan Pengembangan Aktifitas Instruksional Direktorat Jendral Pendidikan Tinggi Departemen Pendidikan dan Kebudayaan.

Imron, Ali. 2015. Integrasi Karakter Positif dan Reduksi Karakter Negatif dalam Supervisi Pembelajaran. http://ap.fip.um.ac.id/wp-content/uploads/2015/04/03-Ali-Imron.pdf (diunduh tanggal 10 Januari 2020)

Kurniadi, A. 2010.Intensitas komunikasi keluarga dan prestasi belajar anak. Skripsi. Program Studi S1 Ilmu Komunikasi Fakultas Ilmu Sosial dan Ilmu Politik Jurusan Komunikasi Universitas Sebelas Maret Surakarta.

Kurniawati Rd. N. Kania. 2014. Komunikasi antar Pribadi; Konsep dan Teori Dasar. Yogyakarta; Graha Ilmu

Mohammad Mustari. 2014. Nilai Karakter Refleksi Untuk Pendidikan. Jakarta : Rajawali Press

Mulyana, Deddy. 2005. Ilmu Komunikasi Suatu Pengantar. Bandung: PT. Remaja Rosdakarya

Moleong, Lexy J. 2005. Metodologi penelitian kualitatif. Bandung: PT Remaja Rosda Karya.

Moleong, Lexy J. 2007. Metodologi Penelitian Kualitatif. Bandung: Remaja Rosdakarya.

Mukhtar. 2013. Metode Praktis Penelitian Deskriptif Kualitatif, REFERENSI (GP pres Group. Jakarta.

Mubarok \& Dwi Adnjani M. 2014. Komunikasi antar Pribadi dalam Masyarakat Majemuk. Makasar; Dapur Buku.

Nurani Soyomukti. 2010. Pengantar Ilmu Komunikasi. Jogjakarta: Ar-Ruzz Media

Sugiyono. 2011. Metode Penelitian Pendidikan Pendekatan Kuantitatif, Kualitatif, dan R \& D. Bandung: ALFABETA, CV.

Satori dan Komariah. 2013. Metodologi Penelitian Kualitatif. Bandung alfa beta.

Sari. A, Hubeis. A. V. S, Mangkuprawira. S \& Saleh. A. 2010. Pengaruh Komunikasi Keluarga dalam Fungsi Sosialisasi Keluarga terhadap Perkembangan Anak. Jurnal Komunikasi Pembangunan. Vol. 08. No. 02. Hal $36-45$.

Solihat Manap. 2005. Komunikasi Orang Tua dan Pembentukan Kepribadian Anak. Jurnal Mediator. Vol. 06. No. 02. Hal $307-312$.

Tim Pakar Yayasan Jati Diri Bangsa. 2011. Pendidikan Karakter di Sekolah; Dari Gagasan Ke Tindakan. Jakarta : Elex Media Komputindo

Thomas Lickona. 2013. Persoalan Karakter; Bagaimana Membantu Anak Mengembangkan Penilaian Yang Baik, Integritas dan Kebajikan Lainnya terj. Juma Abdu Wamaungo. Jakarta : Bumi Aksara.

Yusuf Syamsu. 2001. Psikologi Perkembangan Anak dan Remaja. Bandung: Remaja Rosdakarya. 